\title{
EFEK ROSELLA MERAH KERING TERHADAP KADAR MDA SERUM TIKUS STRAIN WISTAR YANG DI PAPAR ASAP ROKOK
}

\author{
Novera Herdiani ${ }^{1}$, Wiwik Afridah ${ }^{2}$ \\ ${ }^{1,2}$ Fakultas Kesehatan Universitas Nahdlatul Ulama Surabaya \\ e-mail: novera.herdiani@unusa.ac.id
}

\begin{abstract}
Cigarette smoke contains free radicals. Currently the number of smokers in Indonesia are still high. This study aims to analyze the effects of red rosella of dried on the prevention of the increase of Malondialdehyde (MDA) serum of strain wistar rats exposed to cigarette smoke. The total sample of 24 male rats and divided into four groups: negative control, positive control, treatment of red rosella on dried dose $540 \mathrm{mg} / \mathrm{bw}$, and red rosella on dried dose $810 \mathrm{mg} / \mathrm{bw}$. Negative control only given with standard feed. Positive control given by standard feed and exposed to 2 cigarettes a day. Treatment group were feed by standard and red rosella of dried in the morning and exposed to 2 cigarettes after that. This study was conducted for 21 days. At the end of the study, blood serum was analyzed to determine MDA. The results of the study of MDA serum test is analyzed with One Way ANOVA and followed by Tukey LSD test at 5\% level. The giving of red rosella on dried dose $540 \mathrm{mg} / \mathrm{bw}$ and red rosella on dried dose $810 \mathrm{mg} / \mathrm{bw}$ can significantly prevent the increase of MDA serum in strain wistar rats exposed to cigarette smoke.
\end{abstract}

Keywords: red rosella of dried, cigarette smoke, MDA

\begin{abstract}
Abstrak: Asap rokok mengandung radikal bebas. Saat ini jumlah perokok di Indonesia masih tinggi. Penelitian ini bertujuan untuk menganalisis dampak pemberian rosella merah kering terhadap pencegahan kenaikan Malondialdehid (MDA) serum tikus strain wistar yang dipapar asap rokok. Total sampel 24 tikus jantan dan dibagi menjadi empat kelompok: kontrol negatif, kontrol positif, perlakuan rosella merah kering dosis $540 \mathrm{mg} / \mathrm{kg}$ bb, dan rosella merah kering dosis $810 \mathrm{mg} / \mathrm{kg}$ bb. Kontrol negatif hanya diberi pakan standar. Kontrol positif diberi pakan standar dan dipapar 2 rokok per hari. Kelompok perlakuan diberi pakan standar dan rosella merah kering di pagi hari dan setelah itu dipapar 2 rokok. Penelitian ini dilakukan selama 21 hari. Di akhir penelitian, serum darah dianalisis untuk menentukan nilai MDA. Hasil penelitian uji MDA serum dianalisis dengan One Way ANOVA dan diikuti oleh uji $L S D$ pada level 5\%. Pemberian rosella merah kering dosis $540 \mathrm{mg} / \mathrm{kg}$ bb dan rosella merah kering dosis $810 \mathrm{mg} / \mathrm{kg}$ bb dapat mencegah peningkatan MDA serum secara signifikan pada tikus strain wistar yang dipapar asap rokok.
\end{abstract}

Kata kunci: rosella merah kering, asap rokok, MDA

\section{PENDAHULUAN}

Merokok merupakan salah satu faktor penyebab terjadinya penyakit kardiovaskuler yang merupakan penyebab kematian terbesar di dunia. Word Health Organization telah memberikan peringatan bahwa dalam dekade 2020-2030 tembakau akan membunuh 10 juta orang per tahun, 70\% di antaranya terjadi di negara-negara berkembang (WHO, 2008). Menurut Riskesdas
(2013), perilaku merokok penduduk usia $\geq 15$ tahun di Indonesia mengalami peningkatan yaitu sejumlah 36,3\%, dibandingkan Riskesdas sebelumnya. Ditemukan 1,4\% perokok 10-14 tahun, 9,9\% perokok pada kelompok tidak bekerja, dan 32,3\% pada kelompok kuintil indeks kepemilikan terendah. Rerata jumlah batang rokok yang diisap per hari per orang di Indonesia adalah 12-13 batang (setara satu bungkus). Sulit 
untuk menghentikan kebiasaan merokok pada masyarakat. Menurut Voges (2000), nikotin pada rokok dapat menyebabkan ketagihan dan gangguan pada jantung serta paru-paru.

Data Riskesdas 2013, menunjukkan jumlah perokok mengalami peningkatan dan sekitar 69\% rumah tangga memiliki pengeluaran untuk rokok. Hal ini berarti minimal terdapat 1 orang anggota rumah tangga yang mengonsumsi tembakau. Secara nasional 85,4\% perokok usia 10 tahun ke atas merokok di dalam rumah ketika bersama anggota rumah tangga lain. Permasalahannya, menghilangkan kebiasaan merokok bukanlah hal yang mudah. Dalam asap rokok terkandung radikal bebas yang membahayakan tubuh sehingga sementara ini perlu adanya inovasi untuk mengembangkan suatu produk yang dapat meminimalisasi dampak negatif yang ditimbulkan oleh asap rokok.

Secara normal, radikal bebas sudah terdapat di dalam tubuh (radikal bebas endogenous). Tubuh secara alami mempunyai antioksidan yang berperan sebagai inhibitor yang bekerja menghambat oksidasi dengan cara bereaksi dengan radikal bebas reaktif membentuk radikal bebas yang relatif stabil. Apabila radikal bebas terlalu banyak maka antioksidan tersebut tidak mampu mengatasinya, dalam keadaan seperti ini tubuh memerlukan suplai antioksidan (Sofia dan Dinna, 2006), contohnya seperti antioksidan yang terkandung pada rosella merah.

Alternatif dalam mengatasi efek rokok yaitu pemanfaatan rosella merah kering dalam pelarut air. Rosella merah kering dalam pelarut air dapat diaplikasikan sebagai bahan tambahan alami untuk pangan fungsional. Pelarut air cocok untuk mengekstrak antosianin yang mempunyai kepolaran sama dengan air. Selain itu, pelarut air dipilih karena lebih aman dan mudah diaplikasikan dalam skala rumah tangga. Menurut Esa, dkk. (2010), ekstraksi kelopak rosella de- ngan menggunakan pelarut air mempunyai total aktivitas antioksidan paling tinggi dibandingkan biji, daun, maupun batang rosella. Kelopak rosella merah dalam pelarut air mempunyai total aktivitas antioksidan yang tinggi yaitu sebesar $54,1 \%$.

Rosella merah kering banyak mengandung antosianin di mana 1 gram rosella mengandung 56,5 mg delphinidin-3-O-sambubioside dan 20,8 mg cyanidin-3-O-sambubioside (Alarco-Alanso, J., dkk., 2012). Antioksidan dapat menetralisir radikal bebas dengan cara menerima atau mendonorkan sebuah elektron untuk menghasilkan molekul yang lebih stabil (berpasangan). Radikal bebas bisa bersumber dari asap kendaraan, minyak jelantah, dan asap rokok. Menurut Park., dkk. (1998), asap rokok mengandung radikal bebas dalam konsentrasi tinggi.

Komponen kimia yang terdapat dalam asap rokok berupa gas dan partikel. Senyawa gas dan partikel asap rokok beberapa di antaranya bersifat radikal. Radikal bebas banyak yang berumur pendek namun nitrit oksida dan radikal quinones dapat mencapai paru-paru (Tirtosastro dan Murdiyati, 2010). Dari paru-paru radikal bebas dibawa oleh aliran darah menuju ke jantung dan diedarkan ke seluruh tubuh (Guyton dan Hall, 1997).

Sangat ironis, banyak masyarakat yang tidak menyadari dampak negatif rokok. Padahal bahaya rokok sudah tercantum dalam kemasan, bahwa merokok dapat menyebabkan kanker, serangan jantung, impotensi, gangguan kehamilan, dan janin. Dampak tersebut berhubungan dengan adanya kandungan radikal bebas dalam asap rokok seperti $\mathrm{NO}, \mathrm{CO}, \mathrm{NOx}, \mathrm{H}_{2}-\mathrm{O}_{2}$, aldehid, trace elements, dan nitroso compounds (Valvanidis, dkk., 2001).

Berbagai penelitian menunjukkan bahwa asap rokok mengandung berbagai macam bahan oksidan/radikal bebas yang dapat membahayakan 
tubuh manusia. Radikal bebas dapat menyebabkan stress oksidatif yang merupakan muara dari penyakit degeneratif. Adanya peningkatan radikal bebas di dalam tubuh yang tidak diimbangi oleh peningkatan antioksidan endogen akan menimbulkan terjadinya stress oksidatif. Untuk mengetahui terjadinya stress oksidatif tersebut telah dipergunakan berbagai parameter pengukuran di antaranya adalah kadar Malondialdehid (MDA) serum. Malondialdehid merupakan suatu senyawa yang terbentuk selama proses peroksidasi lipid dari asam lemak tidak jenuh ganda (PUFAs = Polyansturated Fatty Acids). Pengukuran kadar MDA serum sampai saat ini merupakan pengukuran yang standar untuk mengetahui adanya stres oksidatif (Murray, dkk., 2009).

\section{METODE}

Jenis penelitian ini yaitu eksperimental laboratorium. Tahap in vivo yang digunakan adalah True Experimental Laboratory dengan posttest only control group design. Rancangan perlakuan pada penelitian ini yaitu rancangan acak lengkap (RAL). Sampel terdiri atas 24 ekor tikus jantan dipilih dengan cara random sampling untuk dibagi dalam satu kelompok kontrol negatif (normal), satu kelompok kontrol positif, dan empat kelompok perlakuan. Setiap kelompok terdiri dari 6 ekor tikus dengan penjelasan sebagai berikut.

1. Kelompok I adalah kontrol negatif (kelompok normal), tidak diberi paparan dan tidak diberi rosella merah kering.

2. Kelompok II adalah kontrol positif, yang diberi air $1 \mathrm{ml}$ p.o selanjutnya diberi paparan asap rokok sebanyak 2 batang.

3. Kelompok III adalah perlakuan yang diberi rosella merah kering dosis $540 \mathrm{mg} / \mathrm{kg}$ bb p.o selanjutnya diberi paparan asap rokok sebanyak 2 batang.

4. Kelompok IV adalah perlakuan yang diberi rosella merah kering dosis $810 \mathrm{mg} / \mathrm{kg}$ bb p.o selanjutnya diberi paparan asap rokok sebanyak 2 batang.

Tahap in vivo dilakukan dengan memberikan rosella merah kering sesuai dosis yang telah ditetapkan. Tahap lainnya meliputi paparan asap rokok selama 21 hari, dan pada tahap akhir dilakukan pengujian bio-assay terhadap nilai MDA serum.

Pakan hewan coba memakai merek POKPHAND CP 591, dengan komposisi kadar air $\max 13,0 \%$, protein $18,0-20,0 \%$, lemak min $3,0 \%$, serat max $6,0 \%$, abu max $7,0 \%$, kalsium min $0,9 \%$, dan phosphor min 0,6\%. Bahanbahan yang dipakai dalam formulasi pakan antara lain jagung, dedak, tepung ikan, bungkil kedelai, bungkil kelapa, tepung daging dan tulang, pecahan gandum, bungkil kacang tanah, tepung daun, canola, vitamin, kalsium, fosfat, dan trace mineral.

Alat yang digunakan dalam membuat ekstrak rosella merah kering adalah spatula, beaker glass, kain saring, magnetik stirer, gelas ukur, botol gelap, kompor, thermometer, timbangan digital dan timbangan analitik (Denver instrument M-310), vacuum evaporator, labu ukur, tabung erlenmeyer. Alat-alat yang digunakan untuk analisis antara lain buret, erlenmeyer, beaker glass, sentrifuse, vortex, tabung reaksi, spektrofotometer, dan pipet.

Bahan yang digunakan dalam penelitian ini adalah rosella merah kering yang diperoleh dari Desa Joho, Kabupaten Kediri, Jawa Timur. Bahan untuk analisis yaitu kertas saring, aquades, $\mathrm{HCl}$, asam asetat, Na-asetat, larutan 1,1-diphenil-2pieryllhydrazil (DPPH) 0,2 M, serum tikus. 
Dosis yang diberikan berdasarkan penelitian sebelumnya yang telah dilakukan Ulilalbab (2012) menyebutkan bahwa ekstrak rosella dosis $540 \mathrm{mg} / \mathrm{kg}$ bb secara efektif mampu mencegah kenaikan MDA serum. Sehingga pada perlakuan pertama penelitian ini menggunakan dosis tersebut, di mana dosis tikus tersebut apabila diaplikasikan ke manusia setara dengan 4 (kelopak) $\mathrm{x}$ 3 (frekuensi konsumsi) dalam sehari dengan berat rata-rata kelopak rosella kering adalah 0,5 g. Pada perlakuan kedua, dosis yang dipakai lebih besar dari dosis pertama, yaitu 6 (kelopak) x 3 (frekuensi konsumsi). Apabila dikonversi ke tikus, maka menjadi $810 \mathrm{mg} / \mathrm{kg}$ bb.

Rokok yang digunakan dalam penelitian ini mengandung nikotin 2,1 mg dan tar sebesar 34 mg. Dosis paparan asap rokok sebanyak 2 batang/tikus/hari. Proses pemaparan dilaksanakan setelah pemberian ekstrak rosella p.o pada kelompok perlakuan. Pemaparan dilakukan di chamber untuk kelompok kontrol positif dan kelompok perlakuan.

Penelitian ini akan dilaksanakan selama 2 bulan dan dilakukan di Fakultas Kedokteran Universitas Wijaya Kusuma Surabaya: pengujian MDA, pembuatan rosella merah kering, pemeliharaan, dan perlakuan hewan coba. Sampel untuk in vivo adalah tikus putih jenis Rattus norvegicus strain wistar jantan dewasa usia 3-4 bulan dengan berat rata-rata 150-200 gram. Metode pengambilan sampel yang digunakan adalah sistem random sampling (rancangan acak lengkap).

Pada tahap awal akan dilakukan analisis normalitas dengan uji Shapiro-Wilk dan uji homogenitas dengan Levene's Test. Apabila didapatkan data normal dan homogen maka selanjutnya dilakukan analisis perbandingan antar-kelompok dengan uji One Way Anova. Apabila ada perbedaan yang signifikan maka pengujian dilanjutkan dengan uji LSD untuk melihat lebih jelas seberapa besar perbedaan tiap kelompok perlakuan.

\section{HASIL}

Tabel 1 Hasil Aktivitas Antioksidan Rosella Merah Kering

\begin{tabular}{|c|c|}
\hline Kode Sampel & \% Inhibisi \\
\hline Dosis 1 $(540 \mathrm{mg} / \mathrm{kg} \mathrm{bb})$ & 44,31 \\
\hline Dosis 2 $(810 \mathrm{mg} / \mathrm{kg} \mathrm{bb})$ & 67,33 \\
\hline
\end{tabular}

Pada Tabel 1 diketahui bahwa aktivitas antioksidan (uji DPPH) yang tertinggi yaitu rosella merah kering dosis $810 \mathrm{mg} / \mathrm{kg}$ bb $(67,33 \%)$ dan terendah pada rosella merah kering dosis 540 $\mathrm{mg} / \mathrm{kg}$ bb yaitu $44,31 \%$.

Berdasarkan hasil penelitian, telah didapatkan gambaran umum kadar MDA serum tikus strain wistar. Hasil analisis rerata kadar MDA serum disajikan pada Gambar 1.

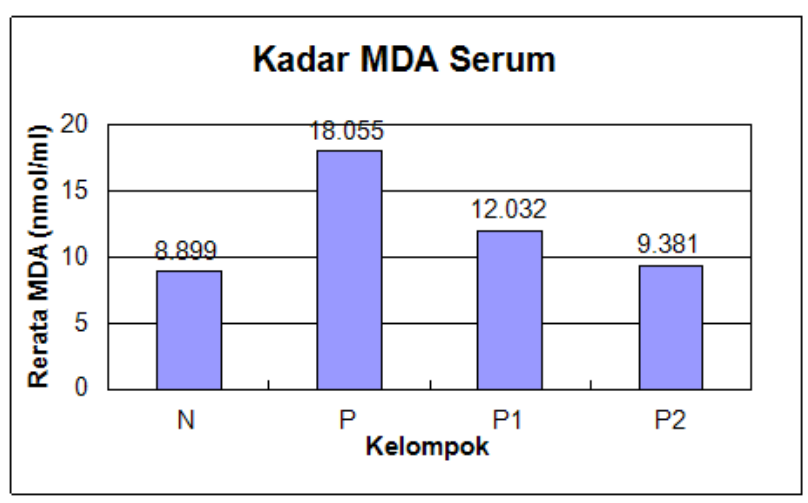

Gambar 1 Rerata MDA Serum Berdasarkan Kelompok

Keterangan:

$\mathrm{N}$ : Kelompok kontrol yang tidak diberi perlakuan

$\mathrm{P}$ : Kelompok kontrol yang diberi asap rokok

P1 : Kelompok perlakuan yang diberi rosella merah kering dosis $540 \mathrm{mg} / \mathrm{kg}$ bb dan diberi asap rokok

P2 : Kelompok perlakuan yang diberi rosella merah kering dosis $810 \mathrm{mg} / \mathrm{kg}$ bb dan diberi asap rokok

Pada Gambar 1 diketahui bahwa rerata kadar MDA kelompok rosella merah kering 
dosis $810 \mathrm{mg} / \mathrm{kg}$ bb yaitu $9,381 \mathrm{nmol} / \mathrm{ml}$. Rerata kadar MDA kelompok rosella merah kering dosis $540 \mathrm{mg} / \mathrm{kg}$ bb yaitu $12,032 \mathrm{nmol} / \mathrm{ml}$. Rerata kadar MDA kelompok kontrol positif yaitu $18,055 \mathrm{nmol} / \mathrm{ml}$. Rerata kadar MDA kelompok kontrol negatif yaitu $8,899 \mathrm{nmol} / \mathrm{ml}$. Kadar MDA serum paling tinggi yaitu pada kontrol positif, sedangkan kadar MDA paling rendah yaitu pada kontrol negatif. Pada kelompok perlakuan, kadar MDA serum yang paling mendekati kelompok kontrol negatif yaitu pada perlakuan rosella merah kering dosis $810 \mathrm{mg} / \mathrm{kg}$ bb.

Tabel 2 Perbedaan Kadar MDA Serum pada Berbagai Kelompok

\begin{tabular}{|l|c|}
\hline \multicolumn{1}{|c|}{ Kelompok } & Rerata \pm SD \\
\hline $\begin{array}{l}\text { Rosella merah kering dosis } 810 \\
\text { mg/kg bb }\end{array}$ & $9,381^{\mathrm{ab}} \pm 1,939$ \\
\hline $\begin{array}{l}\text { Rosella merah kering dosis } 540 \\
\mathrm{mg} / \mathrm{kg} \mathrm{bb}\end{array}$ & $12,032^{\mathrm{b}} \pm 2,915$ \\
\hline Kontrol Positif & $18,055^{\mathrm{c}} \pm 3,191$ \\
\hline Kontrol Negatif & $8,899^{\mathrm{a}} \pm 2,127$ \\
\hline
\end{tabular}

\section{Keterangan:}

Rerata yang didampingi huruf yang sama menyatakan tidak berbeda nyata.

Pada Tabel 2 disebutkan bahwa kadar MDA serum pada kelompok pemberian rosella merah kering dosis $810 \mathrm{mg} / \mathrm{kg}$ bb, tidak berbeda nyata dengan rosella merah kering dosis $540 \mathrm{mg} / \mathrm{kg}$ bb dan kontrol negatif, di mana nilai signifikansi rosella merah kering dosis $540 \mathrm{mg} / \mathrm{kg}$ bb yaitu $p=0,089(p>0,05)$ dan kontrol negatif yaitu $p=0,748(p>0,05)$. Rosella merah kering dosis $810 \mathrm{mg} / \mathrm{kg}$ bb berbeda nyata dengan kontrol positif karena nilai signifikansi $p=$ $0,000(p<0,05)$. Sedangkan untuk rosella merah kering dosis $540 \mathrm{mg} / \mathrm{kg}$ bb, tidak berbeda nyata dengan rosella merah kering dosis $810 \mathrm{mg} / \mathrm{kg}$ bb, di mana nilai signifikansi rosella merah kering dosis $810 \mathrm{mg} / \mathrm{kg}$ bb yaitu $p=0,089$ ( $p>$ $0,05)$. Rosella merah kering dosis $540 \mathrm{mg} / \mathrm{mg}$ bb berbeda nyata dengan kontrol positif dan kontrol negatif, di mana kontrol positif nilai signifikansi $p=0,001(p<0,05)$ dan kontrol negatif yaitu $p=0,048(p<0,05)$.

Pada kontrol positif, kadar MDA serum berbeda nyata dengan semua kelompok yaitu kontrol negatif, rosella merah kering dosis 810 $\mathrm{mg} / \mathrm{kg} \mathrm{bb}$, dan rosella merah kering dosis 540 $\mathrm{mg} / \mathrm{kg}$ bb, setiap kelompok ini memiliki nilai signifikansi $p<0,05$. Sedangkan kelompok kontrol negatif tidak berbeda nyata dengan rosella merah kering dosis $810 \mathrm{mg} / \mathrm{kg}$ bb di mana nilai signifikansi yaitu $p=0,748$ ( $p>$ $0,05)$. Kelompok kontrol negatif berbeda nyata dengan kelompok kontrol positif karena nilai signifikansi $p=0,000(p<0,05)$ dan berbeda nyata dengan rosella merah kering dosis 540 $\mathrm{mg} / \mathrm{kg}$ bb karena yaitu $p=0,048(p<0,05)$.

Kadar MDA serum yang memiliki nilai signifikansi sebesar 0,000 atau $p<0,05$ maka dapat dikatakan ada perbedaan yang bermakna antar kelompok. Selanjutnya dilakukan uji LSD untuk mengetahui perlakuan mana yang dinyatakan berbeda secara bermakna pada uji Anova. Rerata kelompok kontrol negatif, kadar MDA serumnya paling rendah $(8,899 \mathrm{nmol} / \mathrm{ml})$ dibandingkan kelompok lain. Sedangkan kelompok positif kadar MDA serumnya $(18,055 \mathrm{nmol} / \mathrm{ml})$ paling tinggi dibandingkan kelompok lain.

\section{PEMBAHASAN}

Malondialdehid (MDA) adalah salah satu produk akhir radikal hasil peroksidasi lipid yang bersifat toksik terhadap sel hidup. Selain itu, MDA merupakan salah satu ukuran radikal bebas yang terkandung dalam tubuh dan dianggap sebagai biomarker yang sering digunakan untuk mengetahui tingkat stres oksidatif (Santi, 2006). 
Penelitian ini menunjukkan bahwa kandungan aktivitas antioksidan rosella merah kering dosis $810 \mathrm{mg} / \mathrm{kg}$ bb lebih tinggi dibandingkan menggunakan rosella merah kering dosis 540 $\mathrm{mg} / \mathrm{kg}$ bb. Hal ini disebabkan karena kadar antioksidan rosella merah kering dosis $540 \mathrm{mg} /$ $\mathrm{kg}$ bb dosisnya yang lebih kecil dibandingkan dosis $810 \mathrm{mg} / \mathrm{kg}$ bb. Penelitian ini membuktikan bahwa semakin besar dosis yang terkandung pada rosella merah kering, maka aktivitas antioksidan semakin tinggi. Hal ini sejalan dengan penelitian yang dilakukan Ulilalbab (2012), bahwa aktivitas antioksidan rosella dosis yang lebih besar yaitu dosis $540 \mathrm{mg} / \mathrm{kb}$ bb lebih tinggi $(82,81 \%)$ dibandingkan rosella dosis $270 \mathrm{mg} / \mathrm{kg}$ bb $(59,85 \%)$.

Berdasarkan hasil penelitian yang telah dilakukan, rerata kadar MDA kelompok kontrol positif (dipapar asap rokok) adalah 18,055 nmol/ $\mathrm{ml} \pm$ 3,191 lebih tinggi dibandingkan dengan kelompok kontrol negatif (tanpa paparan asap rokok) adalah $8,899 \mathrm{nmol} / \mathrm{ml} \pm$ 2,127.Pada kelompok kontrol positif dengan negatif, kadar MDA serum juga menunjukkan adanya perbedaan yang bermakna $(p<0,05)$. Hal ini menunjukkan bahwa asap rokok dapat meningkatkan kadar MDA.

Hal ini sejalan dengan beberapa penelitian terdahulu bahwa asap rokok akan menyebabkan terjadinya peningkatan kadar MDA seperti penelitian yang dilakukan Lopes dkk. (2013), Kurnia dkk. (2011), Subono, (2007) membuktikan bahwa rata-rata kadar MDA tikus yang terpapar asap rokok, secara signifikan lebih tinggi dibandingkan dengan tikus yang tidak terpapar asap rokok.

Rokok merupakan salah satu sumber eksogen yang dapat memicu terjadinya produksi radikal bebas berlebih dalam tubuh, baik pada perokok aktif maupun pasif, komponen asap rokok terbagi menjadi dua fase yaitu fase gas dan partikulat. Fase gas mengandung radikal bebas dalam bentuk -NO. Fase tar diketahui mengandung radikal dalam bentuk semiquinone (-QH). Mekanisme meningkatmya radikal bebas karena efek langsung dari asap rokok itu sendiri, dan respons imun yaitu aktivasi sel inflamasi, karena beberapa komponen asap rokok bersifat iritan. Radikal bebas yang terdapat di dalam asap rokok merupakan molekul biologik yang memepunyai satu atau lebih elektron yang tidak berpasangan pada orbit terluarnya, sehingga menyebabkan elektron ini tidak stabil dan sangat reaktif dapat merusak jaringan. Paparan asap rokok merupakan salah satu faktor utama meningkatnya radikal bebas dalam tubuh, adapun penyebab lainnya seperti sinar Ultra Violet, asap kendaraan, asap pabrik dan lain sebagainya. Proses tersebut akan menghasilkan ROS (Reactive Oxygen Species) berlebih yang merupakan oksidan utama dalam tubuh (Muliartha, dkk., 2009).

ROS menyebabkan ketidakseimbangan antara oksidan dengan antioksidan yang ada di dalam tubuh sehingga menyebabkan stres oksidatif. Stres oksidatif merupakan suatu keadaan ketidakseimbangan antara radikal bebas dengan antioksidan, ketika jumlah radikal bebas lebih banyak bila dibandingkan dengan antioksidan yang ada di dalam tubuh. Apabila produksi radikal bebas melebihi dari kemampuan antioksidan untuk menetralkannya, maka kelebihan radikal bebas sangat potensial menyebabkan penyakit (Halliwel, dkk., 2007).

Peningkatan ROS mengakibatkan radikal bebas akan bereaksi dengan lemak, protein, dan asam nukleat seluler sehingga hal ini dapat menyebabkan kerusakan lokal dan disfungsi organ tertentu. Lemak sangat rentan terhadap serangan radikal bebas. Mekanisme sel atau 
jaringan akibat serangan dari radikal bebas yang paling awal diketahui dan paling banyak terjadi di membran sel, terutama asam lemak tidak jenuh PUFA yang merupakan komponen penting penyusun membran sel. (Halliwel, dkk., 2007).

Hasil yang diperoleh dari penelitian ini secara preventif menunjukkan bahwa kelompok yang diberi perlakuan rosella merah kering disertai dengan pemberian asap rokok menunjukkan adanya penurunan kadar MDA dibandingkan dengan kelompok yang hanya diberi asap rokok tanpa diberi rosella merah kering. Rerata kadar MDA kelompok rosella merah kering dosis 810 $\mathrm{mg} / \mathrm{kg}$ bb adalah 9,381 $\mathrm{nmol} / \mathrm{ml} \pm 1,939$ dan kelompok rosella merah kering dosis $540 \mathrm{mg} / \mathrm{kg}$ bb adalah $12,032 \mathrm{nmol} / \mathrm{ml} \pm 2,915$, lebih rendah dibandingkan kelompok kontrol positif adalah $18,055 \mathrm{nmol} / \mathrm{ml} \pm 3,191$. Kadar MDA serum kelompok rosella merah kering dosis $810 \mathrm{mg} / \mathrm{kg}$ bb hampir sama dengan rerata kadar MDA kelompok kontrol negatif adalah $8,899 \mathrm{nmol} / \mathrm{ml}$ $\pm 2,127$.

Kelompok kontrol negatif mempunyai rerata kadar MDA serum paling rendah dibandingkan kelompok lain. Hal ini dikarenakan pada kelompok ini tidak diberikan asap rokok sehingga kadar MDA yang dihasilkan cenderung lebih rendah dibandingkan kelompok lain. Sedangkan kadar MDA paling tinggi adalah pada kelompok kontrol positif. Hal ini dikarenakan pada kelompok kontrol positif diberikan paparan asap rokok tanpa diberi asupan sumber antioksidan yang memiliki fungsi dalam menetralisir radikal bebas. Asap rokok merupakan sumber radikal bebas yang dapat menyebabkan stres oksidatif.

Menurut teori Santi (2006) bahwa paparan asap rokok menimbulkan kenaikan kadar MDA. Hal ini disebabkan karena paparan asap rokok menimbulkan radikal bebas. Radikal bebas yang berlebihan akan menimbulkan stres oksidasi. Radikal bebas tanpa adanya antioksidan sebagai peredam menyebabkan kadar MDA serum tikus terus meningkat.

Pada kelompok yang diberi perlakuan rosella merah kering dosis $810 \mathrm{mg} / \mathrm{kg}$ bb dan dosis 540 $\mathrm{mg} / \mathrm{kg}$ bb dengan kelompok kontrol positif menunjukkan adanya perbedaan bermakna $(\mathrm{p}<$ $0,05)$. Hal ini menunjukkan bahwa terjadi penurunan kadar MDA serum pada kelompok yang mendapat perlakuan rosella merah kering. Perlakuan pada hewan coba secara preventif dengan menggunakan rosella merah kering dapat mencegah kenaikan kadar MDA yang diakibatkan oleh paparan asap rokok. Penelitian ini sejalan dengan yang dilakukan Suwandi (2012), bahwa terjadi penurunan kadar MDA sebesar 28,1\% pada kelompok yang diberikan rosella dengan dosis $250 \mathrm{mg} / \mathrm{kg}$ bb dan pada kelompok yang diberikan rosella dosis $500 \mathrm{mg} / \mathrm{kg}$ bb sebesar 50,2\%.

Kelompok perlakuan rosella merah kering dosis $810 \mathrm{mg} / \mathrm{kg}$ bb dan rosella merah kering dosis $540 \mathrm{mg} / \mathrm{kg}$ bb memberikan pengaruh terhadap penurunan tingkat stres oksidatif berupa penurunan kadar Malondialdehid (MDA) yang ditimbulkan oleh asap rokok. Keadaan di mana terjadi ketidakseimbangan antara produksi senyawa turunan oksigen dengan sistem antioksidan tubuh inilah yang memicu kondisi stres oksidatif, di mana salah satu paramaternya adalah peningkatan produksi turunan radikal bebas.

Berdasarkan hasil uji statistik menunjukkan bahwa pada kelompok perlakuan pada uji in vivo memberikan pengaruh nyata $(p>0,05)$ terhadap kadar MDA serum. Sehingga perlu dilakukan uji lanjutan statistik untuk melihat perlakuan mana yang berbeda (perbedaan tersebut dapat dilihat pada lampiran). Perbedaan dosis digunakan untuk melihat pengaruh antara dosis rosella merah kering yang diberikan dengan 
besarnya kadar MDA serum. Kelompok perlakuan rosella merah kering dosis $810 \mathrm{mg} / \mathrm{kg} \mathrm{bb}$ dan dosis $540 \mathrm{mg} / \mathrm{kg}$ bb secara rerata mengalami tendensi penurunan kadar MDA.

Hal ini menunjukkan bahwa pemberian dosis rosella merah kering dosis $810 \mathrm{mg} / \mathrm{kg}$ bb dan dosis $540 \mathrm{mg} / \mathrm{kg}$ bb memberikan pengaruh nyata terhadap penurunan kadar MDA, akan tetapi di antaranya keduanya tidak berbeda nyata. Sebagaimana diketahui rosella merah kering dosis $810 \mathrm{mg} / \mathrm{kg}$ bb merupakan tambahan $1 / 2$ dari dosis $540 \mathrm{mg} / \mathrm{kg}$ bb. Hal ini diduga ekstrak rosella merah dosis $810 \mathrm{mg} / \mathrm{kg}$ bb dan dosis 540 $\mathrm{mg} / \mathrm{kg}$ bb yang diberikan memiliki interval dosis yang pendek, sehingga antar-kelompok rerata kadar MDA serum hampir sama.

Hasil uji lanjutan menunjukkan bahwa kelompok kontrol positif berbeda nyata dengan kelompok kontrol negatif. Hal ini dikarenakan kelompok kontrol negatif yang hanya diberi perlakuan pakan standar saja (normal) tanpa pemberian rosella merah kering dan paparan asap rokok sehingga mengakibatkan kadar MDA serum tikus masih normal $(8,899 \mathrm{nmol} / \mathrm{ml})$ dan paling rendah dibandingkan kelompok lain.

Berbeda dengan kelompok kontrol negatif, kelompok kontrol positif merupakan kelompok yang dikondisikan mengalami stres oksidatif dengan paparan asap rokok. Kadar MDA kelompok kontrol positif paling tinggi $(18,055 \mathrm{nmol} /$ ml) dibandingkan kelompok lain. Hal ini mengindikasikan pada kelompok kontrol positif terjadi stres oksidatif, dikarenakan pada kelompok kontrol positif hanya diberi asap rokok dan pakan standar tanpa pemberian asupan antioksidan. Tidak adanya asupan antioksidan menyebabkan radikal bebas dalam darah mengalami peningkatan yang ditandai dengan peningkatan kadar MDA.
Perlakuan pada hewan coba secara preventif dengan menggunakan rosella merah kering yang mengandung antioksidan dapat mencegah kenaikan kadar MDA yang meningkat akibat paparan asap rokok. Berdasarkan penelitian kadar MDA serum dapat disimpulkan bahwa pemberian rosella merah kering yang mengandung antioksidan dapat menurunkan kadar MDA serum tikus wistar yang diberi paparan asap rokok. Rosella merah kering dosis $810 \mathrm{mg} / \mathrm{kg}$ bb lebih efektif menurunkan kadar MDA serum tikus wistar yang diberi paparan asap rokok.

\section{KESIMPULAN}

Aktivitas antioksidan rosella merah kering dosis $810 \mathrm{mg} / \mathrm{kg}$ bb $(67,33 \%)$ paling tinggi dibandingkan rosella merah kering dosis $540 \mathrm{mg} / \mathrm{kg}$ bb (44,31\%). Ada perbedaan kadar Malondialdehid (MDA) serum antara kelompok kontrol negatif, kontrol positif, dan kelompok perlakuan. Rosella merah kering dosis $810 \mathrm{mg} / \mathrm{kg}$ bb lebih efektif menurunkan kadar Malondialdehid (MDA) serum tikus strain wistar yang dipapar asap rokok. Pada kelompok kontrol negatif, kadar MDA serum paling rendah dibandingkan kelompok lain. Sedangkan kelompok positif kadar MDA serum paling tinggi dibandingkan kelompok lain. Untuk pencegahan agar tidak sampai kondisi stres oksidatif, semua kelompok perlakuan pemberian rosella merah kering mampu mencegah kondisi stres oksidatif yang dipapar asap rokok.

\section{SARAN}

Disarankan mengonsumsi rosella merah, terutama dengan dosis rosella merah 6 (kelopak) x 3 (frekuensi konsumsi) dalam sehari untuk 
memberikan efek antioksidan dalam tubuh dan mencegah timbulnya kondisi stres oksidatif. Perlu dilakukan pengujian dan penelitian lebih lanjut diterapkan pada manusia guna pencegahan radikal bebas khususnya pada manusia yang terpapar asap rokok.

\section{DAFTAR PUSTAKA}

Alarco-Alanso, J., Zamilpa A, Aguilar, F.A. 2012 Pharmacological Characterization of the Dieretic Effect of Hibiscus sabdariffa Linn (Malvaceae) extract. J. Ethnopharmacol, 139: 751-6.

Badan Penelitian dan Pengembangan Kesehatan Kementerian Kesehatan RI. 2013 Riset Kesehatan Dasar (RISKESDAS) 2013. Jakarta www.litbang.depkes.go.id/sites/download/rkd2013/Laporan_Riskesdas2013. PDF (sitasi 20 November 2016).

Esa, N.M., Hern, F.S., Ismail, A., and Yee, C.I. 2010. Antioxidant Activity in Different Parts of Roselle (Hibiscus sabdariffa L.) Extracts and Potential Exploitation of the Seeds. Food Chemistry, 122 (2010) 10551060.

Guyton dan Hall. 1997. Buku Ajar Fisiologi Kedokteran Edisi 9. Jakarta: Penerbit Buku Kedokteran EGC.

Halliwell, B., Gutteridge, J.M.C. 2007. Free Radicals in Biology and Medicine. Fourth edition. New York. Oxford University Press.

Kurnia, H., Permatasari, N., dan Subandi. 2011. Pengaruh Ekstrak Jintan Hitam terhadap MDA dan Sel Spermatogonium Tikus Yang Dipapar Asap Rokok Kretek Subakut. Jurnal Kedokteran Brawijaya, Vol. 26, No. 3. Lopes, A.G., Thiago S.F., Renata T.N., Manuella L., Karla M.P.P., Ari M.S., Ricardo M.B.,
Antonio J.R.S., Samuel S.V., and Luis C.P. 2013. Antioxidant Action of Propolis On Mouse Lungs Exposed to Short-term Cigarette Smoke, BioorganicAnd Medicinal Chemistry, 21 (2013) 7570-7577.

Muliartha, I.K.G., Endang S., dan Yuliawati. 2009 Oral Consumption of Combined Vitamin C dan E Repair Liver Damage Due to Subchronic Exposure to Cigarette Kretek. Jurnal Kedokteran Brawijaya. Vol. XXIV, No.1.

Murray, R.K., Granner, D.K., \& Rodwell, V.W. 2009. Biokimia Harper. Edisi 27. Jakarta: Buku Kedokteran EGC.

Park, E.M., dkk. 1998. Oxidative Damaged Tissue of Rats Exposed to Cigarette Smoke. Free Radicals Biology Medicine.

Santi, S.W. 2006. Pengaruh Pemberian Dekok dan Instan Jahe (Zingiber Officinate Rocs.) Terhadap Kadar MDA Serum, Hepar, dan Paru Tikus (Rattus Norvegicus) yang Dipapar Asap Rokok Kretek Sub Akut, Skripsi. Fakultas Kedokteran Universitas Brawijaya. Malang. Hal 14-15.

Subono, F.A. 2007. Pengaruh Ekstrak Bayam (Amaranthus Tricolor L) Terhadap Kadar MDA dan Aktivitas GSH Px Rattus Norvegicus Strain Wistar yang Terpapar Asap Rokok. Program Studi Ilmu Kedokteran Dasar Universitas Airlangga Surabaya.

Sofia dan Dinna. 2006. Antioksidan dan Radikal Bebas (online) www.chemistry.org.

Tirtosastro, S. dan Murdiyati, A.S. 2010. Kandungan Kimia Tembakau dan Rokok. Buletin Tanaman Tembakau, Serat dan Minyak Industri 2(1), April 2010:33-43.

Valvanidis A., dkk. 2001. A Comparative Study by Electron Paramagnetic Resonance of Free Radicals Species in The Main Steam and Side Stream Smoke of Cigarettes with 
Conventional Accate Filters and Biofilters, Medline Journal. England.

Voges, E. 2000. Tobacco Encyclopedia. Tabac Journal International, Mainz, Germany, $279 \mathrm{p}$.
World Health Organization. 2008. WHO Report on the Global Tobacco Epidemic 2008, 3-8. New York: WHO Publisher. 